\title{
Physico-Chemical Features and Subsurface Nature of Coastal Dunes on Bozcaada Island, NW Turkey
}

\author{
Mustafa Avcıŏlu', Ahmet Evren Erginal,"*, Muhammed Zeynel Öztürk ${ }^{3}$, Alper \\ Demirci $^{4}$, Yunus Levent Ekinci ${ }^{5}$, Murat Türkeş ${ }^{6}$, Ersin Karabacak ${ }^{7}$, Ali Sungur ${ }^{8}$, \\ Hasan Özcan ${ }^{8}$, Rezzan Ekinci', Gülsen Erginal ${ }^{10}$
}

\author{
${ }^{1}$ Çanakkale Onsekiz Mart University, Department of Geological Engineering, 17020, ÇANAKKALE-TR \\ ${ }^{2}$ Ardahan University, Department of Geography, 75000, ARDAHAN-TR \\ ${ }^{3}$ Niğde University, Department of Geography, 51240, NIĞDE-TR \\ ${ }^{4}$ Bitlis Eren University, Department of Geophysical Engineering, 13000, BITLIS-TR \\ ${ }^{5}$ Bitlis Eren University, Department of Archaeology, 13000, BITLIS-TR \\ ${ }^{6}$ Middle East Technical University, Affiliated Faculty at the Department of Statistics, 06800, ANKARA-TR \\ ${ }^{7}$ Çanakkale Onsekiz Mart University, Department of Biology, 17020, ÇANAKKALE-TR \\ ${ }^{8}$ Çanakkale Onsekiz Mart University, Department of Soil Sciences, 17020, ÇANAKKALE-TR \\ ${ }^{9}$ Bitlis Eren University Campus, Lodging Buildings, R4 No: 20, 13000, BITLIS-TR \\ ${ }^{10}$ Ardahan University, Vocational School of Çıldır, 75400, ARDAHAN-TR
}

Corresponding author. Tel: +90 5349264784

Received 28 Nov 2014

E-mail: aerginal@gmail.com

Accepted 05 Jan 2015

\begin{abstract}
We studied the composition, vegetation cover, wind regime characteristics and subsurface nature of a coastal dune field on the west coast of Bozcaada Island, NW Turkey. Performing Electrical Resistivity Tomography (ERT) technique, we determined that dune sands with a thickness of $\sim 11-13 \mathrm{~m}$ cover the underlying Miocene basement, as confirmed by an abrupt increase in resistivity as from lithological boundary. The results demonstrate that foredune terraces and ridges differ from swales from various points of view. The foredune sands are characterized by average contents of over $82 \%$ medium to fine-sized angular sands, especially quartz (85\%), based on X-ray fluorescence spectroscopy (XRF) data, $\mathrm{CaCO}_{3}(1.15 \%)$ and organic matter $(0.19 \%)$. On the other hand, swales are composed on average of 59\% medium to fine sands, a mixture of silt and clay (13\%), very coarse sands and small-size gravels $(28 \%)$. In addition to the different grain size distribution, swale sediments have conspicuously lesser amounts of $\mathrm{SiO}_{2}(78 \%)$, higher amounts of $\mathrm{CaCO}_{3}(5.6 \%)$ and organic matter $(0.8 \%)$. Wind climatology analysis showed the predominance of a northerly (mainly NNE) near surface wind circulation over Bozcaada throughout the year with high wind speeds of maximum $7.4 \mathrm{~m} / \mathrm{s}$. Nevertheless, the existing sand transport and associated development of foredune forms and blowouts in the dune field relates considerably to the bimodal distribution of northerly winds (NNW and NNE). Although the coastal dune area is capped by a variety of dune plants, blowout development is highly active, in particular, on the northeast section of the dune field.
\end{abstract}

Keywords: Dune sand, electrical resistivity, wind climatology, Bozcaada Island, NW Turkey.

\section{Introduction}

Turkey has a long shoreline $(8333 \mathrm{~km}$ including the Sea of Marmara and islands) because it is circumvented by the Black Sea (1701 km-long) to the north, the Aegean Sea (3484 km-long) to the west and the Mediterranean (1707 km-long) to the south (Sesli et al. 2009). A great quantity of sediment consisting of approximately 175 million $\mathrm{t}^{-1}$ is discharged by sediment-laden rivers into these seas as well as lakes and water reservoirs (Öztürk, 1996). However, this value may reach up to 450 million $\mathrm{t}^{-1}$, which exceeds the average sediment transportation rate of 320 $\mathrm{mt}-1$ of the European continent (Hamidi and Kayaalp, 2008). Thus, sediment transport to Turkey's coasts favors the development of coastal sand dunes, particularly on prograding deltaic environments and sheltered bays (Özcan, et al. 2009a). Özhan, (2005) reported that the total length of coasts where coastal dunes occur is $845 \mathrm{~km}$ in 110 different locations in Turkey (Uslu, 1989). Albeit this wide distribution, our knowledge of the 
physico-chemical characteristics, flora and wind regime of the dune fields is rather scanty (Serteser, 2004; Özcan, et al. 2009a, b; Erginal, et al, 2009).

In this study, we are concerned mainly with the characteristics of coastal dunes on the west coast of Bozcaada Island, NW Turkey (Fig. 1a). We identified the morphological, floristic and physico-chemical characteristics of the coastal dunes on the basis of geomorphological observations, grain size measurements, X-ray fluorescence spectroscopy (XRF) and scanning electron microscopy/energy dispersive X-ray spectroscopy (SEM/EDX) data. Electrical resistivity tomography (ERT) was used to define subsurface geometry of coastal dunes and underlying Miocene basement

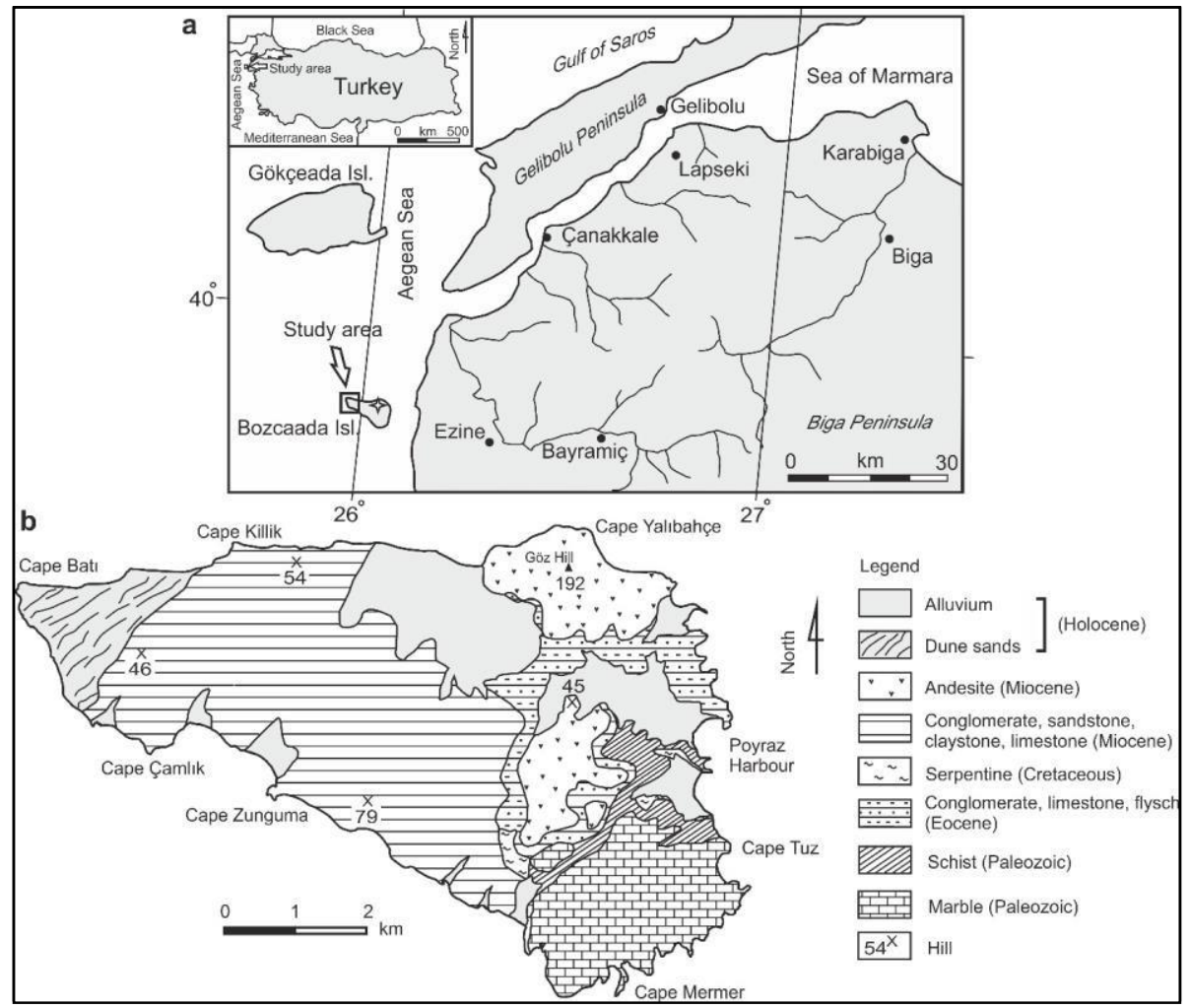

Figure 1. (a) Location map and (b) geology map of study area.

\section{Physical Settings}

Bozcaada Island, located $6 \mathrm{~km}$ west of the Biga Peninsula, NW Turkey, is a small island with an area of $36 \mathrm{~km}^{2}$. The basement rocks on the island comprise marble and schist of Paleozoic age, which are overlain by Eocene basal conglomerate and flysch. Miocene is of widest extension, consisting of conglomerate, sandstone, claystone, limestone and andesite (Erguvanlı, 1955; Kalafatçığlu, 1963; Fig. 1b). The Holocene units are composed of alluvial deposits, beachrock, eolianite and coastal dunes (Kiyak and Erginal, 2009).
According to the rainfall regime classification of Turkey by Türkeş (1996, 1998), the study area has a Mediterranean-type rainfall regime. The period from April to October is mainly characterized by insufficient precipitation while the maximum precipitation shows up in the winter months. In terms of long-term averages, December is the wettest month $(86 \mathrm{~mm})$. The driest month, however, is August (about $5 \mathrm{~mm}$ ). With respect to the monthly mean temperatures, the coldest and warmest months are February $\left(8.3^{\circ} \mathrm{C}\right)$ and July $\left(23.1^{\circ} \mathrm{C}\right)$, respectively. The island is of great significance for wind power production. In fact, the Bozcaada Wind Energy 
Plant (BORES) forms the biggest available wind energy power plant in Turkey. It has reached an output of 131.35 MW (Şahin, 2008). Based on the Thornthwaite's Moisture Index $\left(\mathrm{L}_{\mathrm{m}}\right)$ (1948), a dry sub-humid climate type is dominant at the Bozcaada station; a detailed climatic description is as follows: dry sub- humid, second mesothermal throughout the year, little or no water surplus during the year, with a summer concentration of thermal efficiency equal to a megathermal climate.

In the study area, the beach is sandy and is covered in many places by marine debris formed generally by Posidonia oceanica (L.) Delile. The western promontory of the area is a rocky coast formed by low (1-2 m) sea cliffs and wave-cut platforms cut in Miocene limestone. The dune field, which encompasses an area of $2.25 \mathrm{~km}^{2}$, constitutes $6 \%$ of the total surface area of the island. Coastal dunes lie between latitudes $39^{\circ} 50^{\prime} 48^{\prime \prime}-39^{\circ} 47^{\prime} 14^{\prime \prime}$ 'north and longitudes $25^{\circ} 57^{\prime} 44^{\prime \prime}-26^{\circ} 04^{\prime} 59^{\prime \prime}$ east. The dune field extends about $1.9 \mathrm{~km}$ on a southwest-northeast axis and has a rich plant community, consisting of 55 genus and 58 species belonging to 27 families (Karabacak et al. 2008).

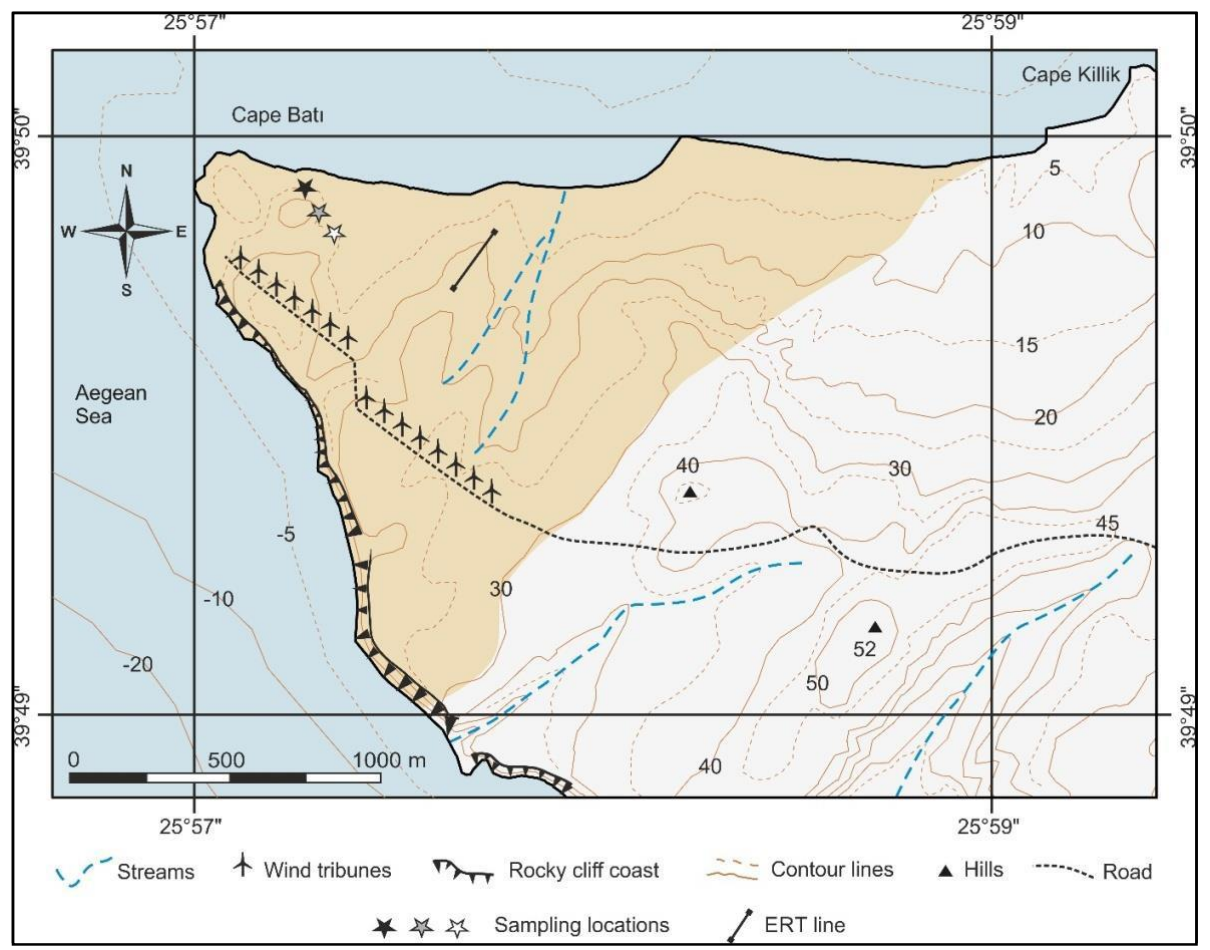

Figure 2. Map of sampling sites and ERT survey line. Black, gray and white stars show sampling pits from foredune terraces, ridges and swales, respectively.

\section{Data and Methods}

\section{Sampling and Dune Sand Analyses}

During field studies, different morphotypes of coastal dunes were recorded using GPS (Garmin ETREX). A total of 13 samples were taken from various depths of sampling pits dug along a representative line into incipient foredune terraces, ridges and swales (Fig. 2).
Sand samples were extracted from different horizons in consideration of their distinctive features (Soil Survey Staff 1993). From each sample of about 500 gr weight, $\mathrm{CaCO}_{3}(\%)$, electrical conductivity (EC), organic matter content and $\mathrm{pH}$ were measured. A Scheibler calcimeter (Schlichting and Blume, 1966) was used to determine total $\mathrm{CaCO}_{3}$ contents. $\mathrm{pH}$ measurements were performed using a WTW 
multi-parameter instrument (Grewelling and Peech, 1960). The content of organic matter within the samples was determined based on the Walkley-Black acid digestion method (Schlichting and Blume, 1966). A subsample weighing $200 \mathrm{~g}$ from each sample was also subjected to analysis by the hydrometry technique (Bouyoucos, 1951) in order to determine total clay, silt and sand contents.

To determine major oxides within samples, XRF analyses were carried out. The same samples were also analyzed by SEM (ZEISS EVO 50 EP) coupled with EDX (Bruker AXS XFlash) to understand the elemental composition and morphology (shape and size) of dune sands. These analyses were carried out in the Materials Research Centre of Izmir Institute of Technology. The Flora of Turkey (Davis, 1965-1985) was the main source used to identify plant specimens. Some doubtful identification was checked in Flora Europaea (Tutin et al. 1964-1980). Plants included in this list were deposited in the herbarium of the Biology Department of Çanakkale Onsekiz Mart University.

\section{Wind and Water Budget Analyses}

In the study, the monthly mean air temperature $\left({ }^{\circ} \mathrm{C}\right)$ and monthly total precipitation $(\mathrm{mm})$ series along with the long-term average wi nd speed $(\mathrm{m} / \mathrm{s})$ and monthly frequency of wind directions recorded at Bozcaada meteorology station of the Turkish State Meteorological Service (TSMS) were used. Long-term averages of wind speed and monthly frequency of wind directions were analyzed to determine the surface wind climatology. Thornthwaite's climate classification and water budget were calculated in consideration of the approach used in the WATBUG program (Willmott, 1977). For the ware budget, we calculated the following parameters: unadjusted potential evapotranspiration (UPE) in $\mathrm{mm}$; adjusted $\mathrm{PE}$ (APE) in $\mathrm{mm}$; soil moisture storage (ST) in $\mathrm{mm}$; actual evapotranspiration (AE) in $\mathrm{mm}$; soil moisture deficit (DEF) and soil moisture surplus (SURP) in $\mathrm{mm}$. Monthly PE values were calculated according to the Thornthwaite (1948) methodology. On the other hand, we calculated the Thornthwaite's Moisture Index using Thornthwaite's (1948) methodology as:

$$
L_{m}=(100 S-60 D) / P E
$$

where, $\mathrm{S}$ is annual water surplus ( $\mathrm{mm}$ ) and $\mathrm{D}$, annual water deficit (mm); PE is annual adjusted potential evapotranspiration $(\mathrm{mm})$. Negative values of the moisture index are found in dry climates, while positive values are found in moist climates.

\section{ERT Survey}

ERT technique is an efficient geophysical tool to map the electrical resistivity characteristic of the subsurface. The technique offers fast and cost-effective high-resolution imaging of near surface resistivity pattern of shallow regions to depths of several tens of meters and provides useful information for characterizing disparate subsurface discontinuities, which can point to lithological variations (Erginal et al., 2013). Thus, in this study we used ERT technique to map both the thickness of the coastal dunes and its contact relation with the underlying bedrock. A line (Fig. 2) orientated nearly perpendicular to the coastline was assigned in the dune field considering one of the representative areas where coastal dunes have a thick accumulation of drifted sands. The apparent resistivities were gathered by means of GF ARES multi-electrode resistivity-meter system, with 41 electrodes spaced at $5.5 \mathrm{~m}$ intervals covering a total length of $220 \mathrm{~m}$. Dipole-dipole electrode configuration was used for 10 data levels with dipoles of 5.5 and $11 \mathrm{~m}$, and unit dipole separations of $1,2,3$, $4,5,6,2.5$ and $3.5 \mathrm{~m}$. The inversion of the measured apparent resistivity values was performed using the software package RES2DINV, which constructs a subsurface resistivity model based on iterative smoothnessconstrained least squares (Loke and Barker, 1996). Due to the significance topographical relief along the survey line, the elevations of each electrode were measured by optical levelling and the topographical data were incorporated into inversion model for a more realistic interpretation. 


\section{Results and Discussions}

\section{The Nature of Incipient Foredunes (Terraces and Ridges)}

In the studied dune field, incipient foredunes dominate the dune morphology. To define their nature, samples were collected from both terraces and ridges (Fig. 3a and b).

The measurement results obtained from a seafacing slope of the dune terraces showed that sand is the predominant component (average $98 \%$ ), characterized by angular quartz grains (Fig. 3c). More than $82 \%$ of dune materials belong to grain sizes ranging between 0.5 and 0.163 , implying the predominance of medium to fine-grains. The clay and silt contents have proportions of $1.47 \%$ and $5.55 \%$, respectively. Electrical conductivity values increase with depth. $\mathrm{CaCO}_{3}$ and total organic matter contents are found in low amounts. XRF analyses also demonstrate that major oxides are found in descending order of confirming the prevalence $\mathrm{SiO}_{2}>\mathrm{Al}_{2} \mathrm{O}_{3}>\mathrm{K} 2 \mathrm{O}>\mathrm{CaO}>\mathrm{Na} 2 \mathrm{O}>\mathrm{Fe}_{2} \mathrm{O}_{3}>\mathrm{TiO}_{2}$ $>\mathrm{MgO}$ of quartz and plagioclase (Table 1 ) with no notable variation in the detected values. EDX results obtained from the same P1-1 and P1-4 also exhibit the existence of various elements in decreasing order of $\mathrm{O}>\mathrm{Si}>\mathrm{C}>\mathrm{Al}>\mathrm{K}>\mathrm{Fe}>\mathrm{Mg}>\mathrm{Ca}$ (Table 1 ).

$\mathrm{SiO}_{2}$ dominates with an average amount of $85 \%$, confirming XRF results. None of the elements show a meaningful trend in depth in vertical section. The foredune terraces are covered with several salt-tolerant plant species shown in Table 2, consisting primarily of Otanthus maritimus.

Foredune ridges ( $\mathrm{P} 2$ in Table 1) are, on the other hand, located behind the incipient dune terraces and are separated by transversal swales and blowouts (Fig.3d). They have elevations up to 10 meters and sharp crests owing to the development of through blowouts. Unlike dune terraces, ridges are not symmetrical in plan view. Their long axes are oblique to the present trend of the shoreline where they are interrupted by blowouts. Several types of dune plants well adapted to sea salt were observed on the ridges, dominated by Ammophila arenaria subsp. Arundinacea, Eryngium maritimum, and Otanthus maritimus (Table 2).
The measurements acquired from dune ridges showed an average of $93 \%$ for sand-sized grains. Similar to the foredune terrace sands, medium to fine-grains ranging in size between $0.5 \mathrm{~mm}$ and $0.163 \mathrm{~mm}$ are found in an average amount of $82 \%$. The $\mathrm{pH}$ is slightly alkaline. EC values are significantly lower and major oxides are similar to those of the sands of foredune terraces. This is also the case for XRF data.

\section{The Nature of Swale Materials}

These interdune depressions have a large extension in the studied dune field and lie between northeast-southwest trending dune ridges. Swales actually follow morphologically former dry valleys, the edges of which were covered by dune ridges (Fig. 3e). On the northeast-inclined bottoms of these depressions, there is enrichment in vegetation cover listed in Table 2. Several physico-chemical characteristics and quantitative elemental analyses results from swale samples (P3 in Table 3) show that coarse and very coarse sands have an average amount of $28 \%$. Medium and fine sands are, however, found in the proportion of about $59 \%$. The rest $(13 \%)$ of the composition is composed of a mixture of very fine sands and silty clay. All sand-size components have very poor roundness (Fig. 3f), similar to that of the foredune sands.

When compared with the foredune sands, this distribution indicates a conspicuous augmentation in the ratio of fine sediments $(\leq 0.163 \mathrm{~mm})$. The other differences are represented by an increase in the contents of total average organic matter and $\mathrm{CaCO}_{3}$ as well as a decrease in the values of EC. In terms of the quantity of major oxides, XRF data display a similar distribution ratio to that of the foredune sands with the exception of an increase in $\mathrm{CaO}$ content. The EDX results from samples (Table 3) collected from the near surface (P31) and bottom (P3-3) of the sampling pit dug in the swale depression yielded more disparities, depicted by the elements aligned in descending order of $\mathrm{O}>\mathrm{Si}>\mathrm{C}>\mathrm{Al}>\mathrm{Fe}>\mathrm{Ca}>\mathrm{K}>$ $\mathrm{Mg}$. All these data suggest that the chemical composition, grain size distributions, organic matter and $\mathrm{CaCO} 3$ contents of swales differ from foredune materials. 
Wind Regime, Moisture Conditions and

Blowout Development

The wind characteristics of the island favor the development of various coastal dune forms in the study area. A Quickbird satellite image (Fig.4a) shows concordance of dune forms with the prevailing wind circulation. In particular, the distinct development of foredune ridges and blowouts is directly connected to the wind regime and surface moisture conditions during the dry season.

Wind turbines clearly indicate that, even though NNE is the prevailing wind of Bozcaada, northerly winds have a bimodal wind direction distribution, characterized by NNW and NNE (Fig.4b and c). The Bozcaada station shows strong long-term average annual mean wind speeds of about $7 \mathrm{~m} / \mathrm{s}$, exceeding this for both northerly (NNE) and southerly (S) surface wind circulations at ten meters over the study area (Table 4). Prevailing winds blow from NNE in all months except for June. In the months of May, June and July, the frequencies of north north-westerly and north north-easterly winds are nearly equal to each other. However, the prevailing wind direction is north north-west (NNW) only in June with a frequency of $21.87 \%$, slightly more than that from NNE with a ratio of $21.47 \%$ (Fig.5).

During a long period of the year, particularly from November to April, southerly sector winds (mainly SSW, S, and SSE) also become somewhat effective in addition to the northerly sector winds. This is directly related to the increased number of mid-latitude and Mediterranean frontal cyclones in these months due to the significant seasonal migration of the polar front and associated upper-air polar jet to relatively low latitudes, leading to westerly and south-westerly air flows over the Mediterranean basin towards Turkey (Türkeş, 1998; Türkeş and Erlat, 2005; Türkeş et al. 2009).

Based on the assumption that the wind-blown removal of sand deflation is controlled by surface moisture conditions, a Thornthwaite water budget was prepared. The water budget shows that the island receives very low annual and monthly precipitation (Table 5).
The results obtained show a soil moisture surplus in winter months and a soil moisture deficit from May to October. The soil moisture deficit is particularly pronounced in July and August. The soil moisture surplus period is shortest through the months of January, February and March when the amount is lowest, with a total of $114 \mathrm{~mm}$. The period of the soil moisture deficit (total of $443 \mathrm{~mm}$ ) dominates over six months from May to October with severe summer dryness in July and August. November is a transition month when the water begins to accumulate in the soil, and the moisture increases due to the start of frontal precipitation events associated with both mid-latitude and Mediterranean cyclones over the region, respectively. Based on these results, the surface of the dune field is rather dry during the period between May and August.

The aforementioned wind characteristics and surface moisture conditions are of prime importance in deflation and erodibility of dune sands, thereby, in particular, allowing the development of blowouts and foredune ridges deprived of vegetation cover. In many places, several deflation basins occur on the crests of vegetation-deprived substrates of asymmetric ridges as result of the easy removal of dune sands.

These erosion hollows are blowouts sensu strictu and are either through or saucer-shaped, as being common elsewhere (Cooper, 1958; Bate and Ferguson, 1996; Hesp, 2002); the latter convert in several places into cup-or bowl-shaped depressions, encased in very coarse sands and very fine gravels, owing to the wind-induced deepening of shallow saucer blowouts (Hesp, 2002). The paragons of these circular or ellipsoidal-shaped depressions (diameter: 25x25 m and 25-60 m; depth: max: $10 \mathrm{~m}$ ) are found in the southwest and west of the dune field and are located at the head of the through blowouts (Fig. 6a).

The deepening of these deflation basins is known to be associated with accelerated wind speed on or near the surface of the depression caused by the angle of incidence of effective winds (Hugenholtz and Wolfe, 2009), which is a well-known wind flow circulation pattern in coastal dune blowouts (Fraser et al. 1998; 
Wang et al. 2007). Actually, with the lack of accurate near surface wind data, mean surface (10 meters) monthly wind speeds of Bozcaada show strong values $(\max : 7.4 \mathrm{~m} / \mathrm{s}$ ) (Table 4). Maximum wind speeds are mostly related with the N, NNE and NNW directions and partly with S and SSE directions both annually and in all months.

The through blowouts, however, are characterized by elongated depressions (Fig.6b), having steep and sharp lateral walls stabilized by dune plants. These dunes have long NE-trending axes that extend up to $600 \mathrm{~m}$. Field observations showed that several blowouts seem to have ingenerated on the apex of foredune ridges and are weakly stabilized by plant canopies at both their margins. The removal of dune sands and subsequent initial opening of a blowout in these parts is likely associated with the accelerated speed of surface winds that act on the wide crests of foredunes (Smith1960). The bottom of the depressions, however, are stony and paleo soil-like; this coincides in many places with a surface of underlying fossiliferous Miocene limestones (Fig.6b), suggesting over-deepening through the stripping of loose blowout sands by northeast and southwest winds.

\section{Subsurface Nature of Coastal Dunes}

Figure 7 shows the model resistivity section with corrected topography, obtained after 5 iterations with an RMS error of $12 \%$. The SW$\mathrm{NE}$ trending two-dimensional resistivity image displayed a depth range of $\sim 17 \mathrm{~m}$. The overall resistivity range in the image is $\sim 15-$ to 2600 ohm-m. The resistivity tomogram obtained along a rugged and undulate topography crossing dune ridges, blowouts and parabolic dune depressions shows a clear contrast from the top down to the transition level cutting the underlying Miocene formations. The transition level lying at a depth between $13 \mathrm{~m}$ and $15 \mathrm{~m}$ is represented with a resistivity of $\sim 150 \mathrm{ohm}-\mathrm{m}$. From this level towards the deeper parts, resistivity values display an increasing trend, pointing to bedrock. The morphology carved in bedrock buried by dune sands is characterized by former valleys formed by NW flowing small streams on southwest-dipping Miocene strata. Throughout the contact level with the resistive basement, dune sands show a conformable accumulation on the buried hummocky topography, which continues up to the surface of coastal dunes.

Nevertheless, coastal dunes display lower resistivity values less than $30 \mathrm{ohm}-\mathrm{m}$ with the exception of those determined in horizontal distance between $33 \mathrm{~m}$ and $132 \mathrm{~m}$. This abnormal increase up to $2600 \mathrm{ohm}-\mathrm{m}$ was obtained along sharp dune crests due to the lack of lateral support that affects the resulting resistivity. This is confirmed by normal resistivity values between the distances of 148 $\mathrm{m}$ and $220 \mathrm{~m}$ of the survey line where coastal dunes have a uniform morphology sloping gently towards the sea. As result, ERT image demonstrated the depth of buried Miocene basement, the subsurface morphology of dune sands and the contact relationship between these two units.

\section{Conclusions}

We studied coastal sand dunes that rest on fossil-bearing Miocene limestones. Morphologically, various dune forms occur, such as saucer or ellipsoidal-shaped interdune depressions or blowouts, incipient foredune terraces and ridges and swales. ERT image obtained along a representative transect passing foredune ridges and blowouts displayed that dune sands have a thickness of about 11-13 m, which slightly increase seawards.

Towards the eastern most part of the dune field, relatively more fixed dunes exist. The dune field eventuates in a forest land comprising Pinus brutia developed on the basement rocks. The measured parameters of dune sands and effective wind climate yielded some consequential data on the nature and dynamics of the dune field. Foredune and swale sands were found dissimilar in recognition of both their content and grain sizes. Bidirectional (NW and SW) near surface wind circulation and long-term average high wind speeds account for the development of dune morphology. Not withstanding the fact that the dune sands are capped by a number of plant species, effective wind activity does not render dune stabilization possible, except for swale depressions, which are covered with dense plant communities. Our study revealed that a combined interpretation of 
the nature of dune sands, climatic data and geophysical imaging give useful insights into dune sand environments.
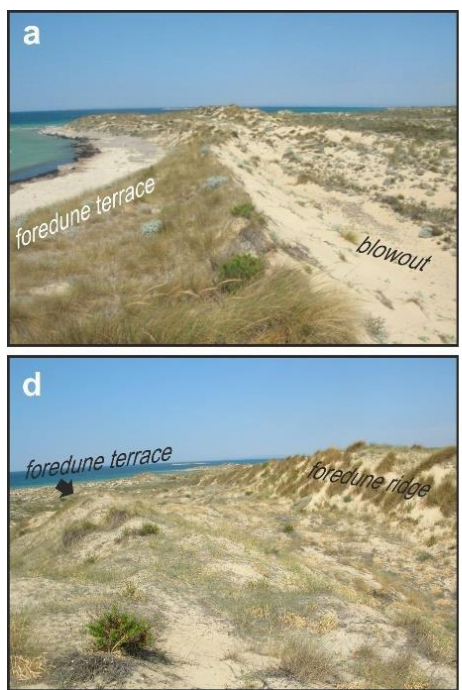
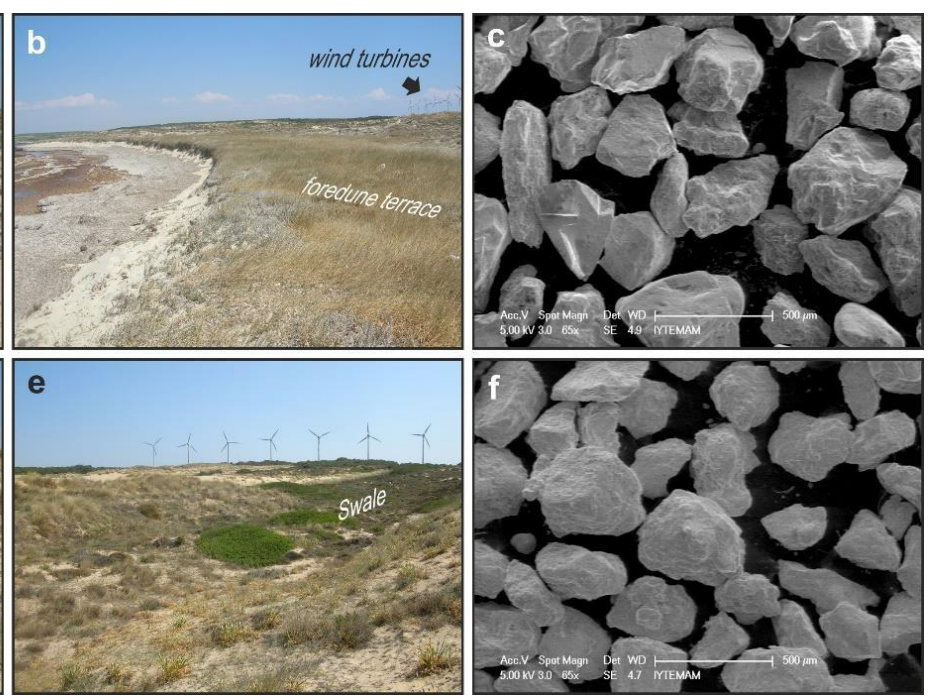

Figure 3. Field pictures and SEM images from the dune field. ( $a$ and $b$ ) Incipient foredune terraces along north beach. (c) SEM image of dune sands extracted from foredune terrace (sample P1-1 in Table 1). (d) Foredune ridges on northeast coast. (e) Swale near wind turbines on northwest coast. (f) SEM image of swale sands (sample P3-4 in Table 2).

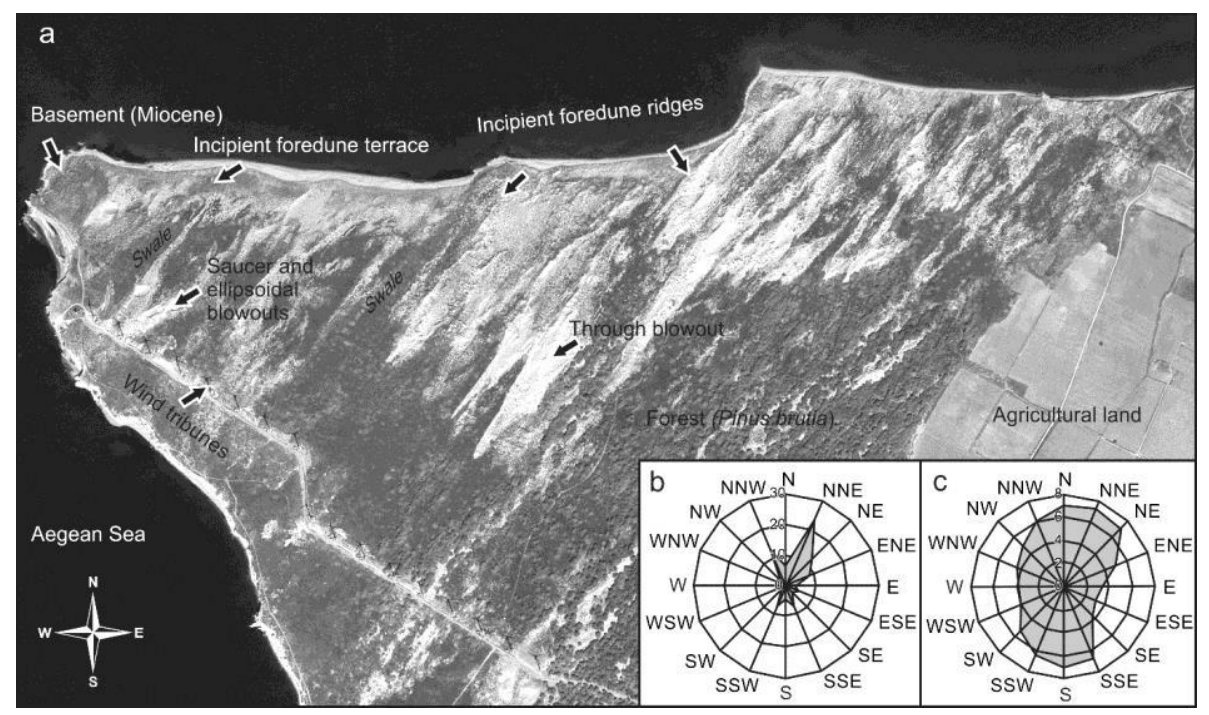

Figure 4. (a) Quickbird satellite image (2008) of dune field. (b) Long-term annual wind direction frequencies (as percentages), and (c) annual mean wind speeds $\left(\mathrm{m} \mathrm{s}^{-1}\right)$ of Bozcaada meteorology station. 


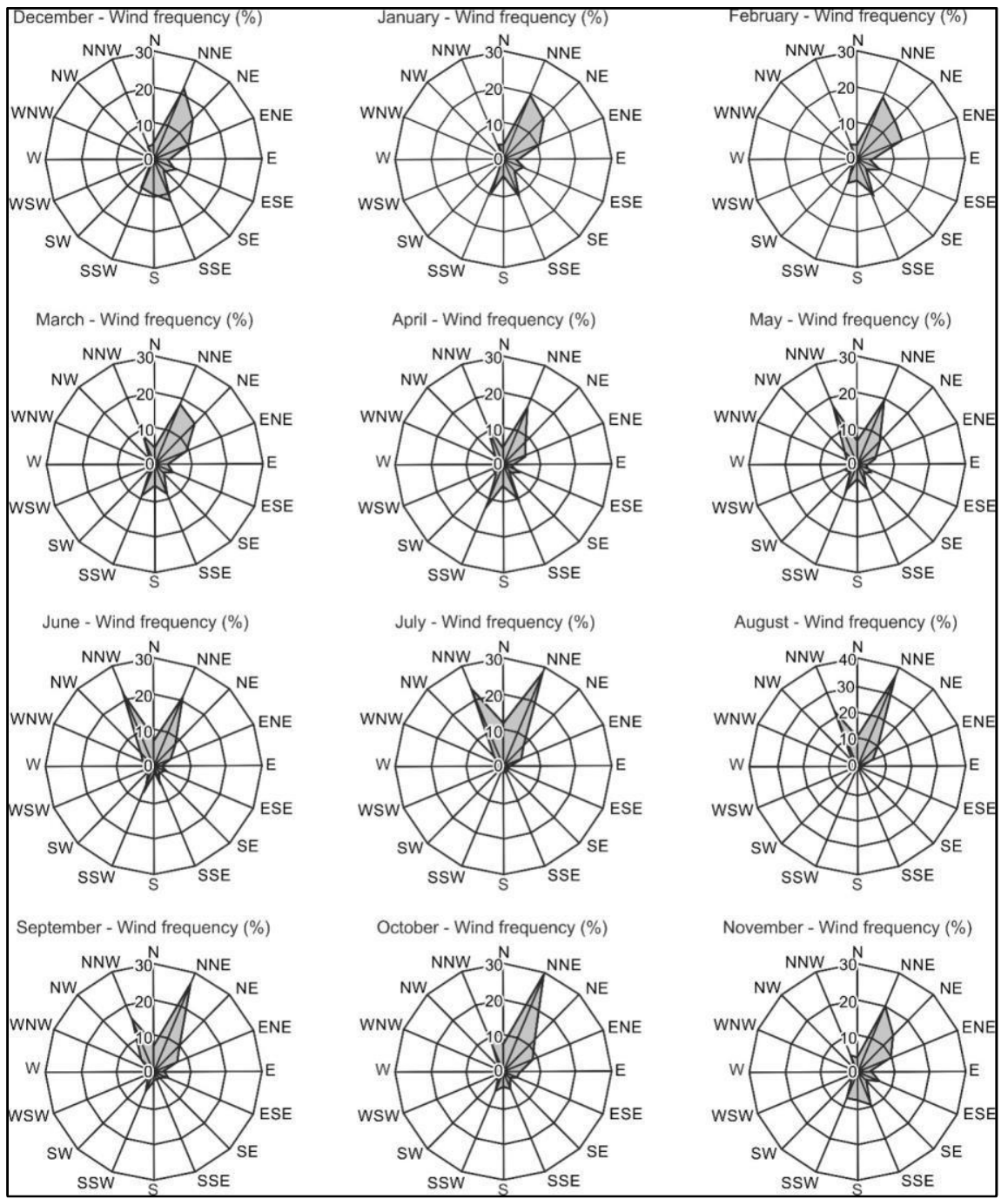

Figure 5. Monthly variations of wind direction frequencies (as percentages) of Bozcaada station.

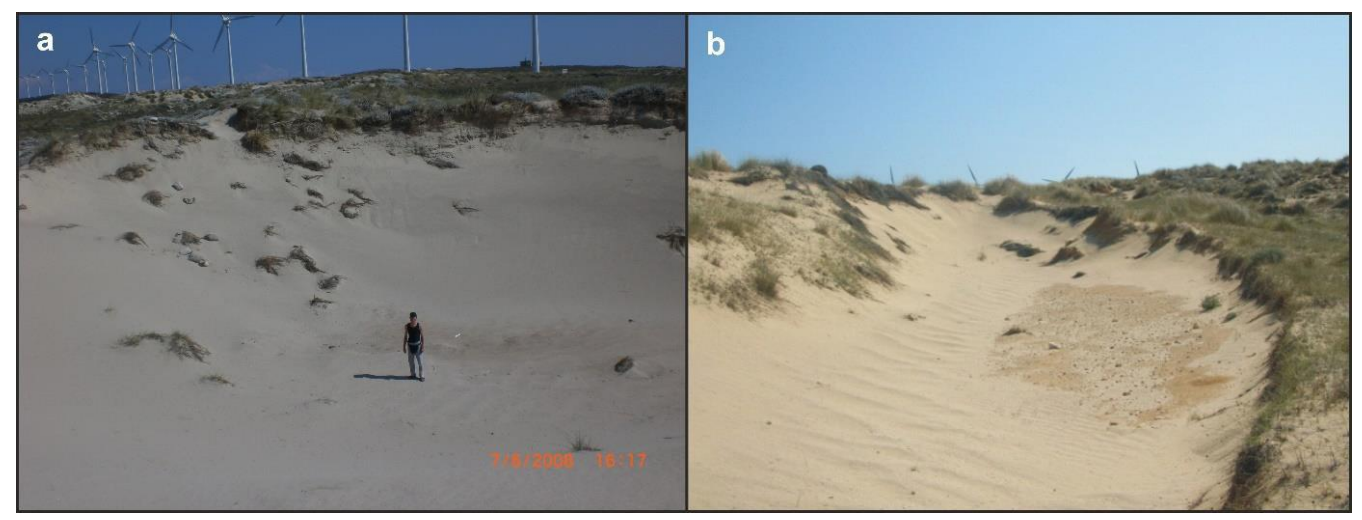

Figure 6. (a) Saucer-shaped blowout. Please see person's height for scale $(1.80 \mathrm{~m})$. (b) Shallow through blowout, bottom of which corresponds to emerged Miocene basement. 


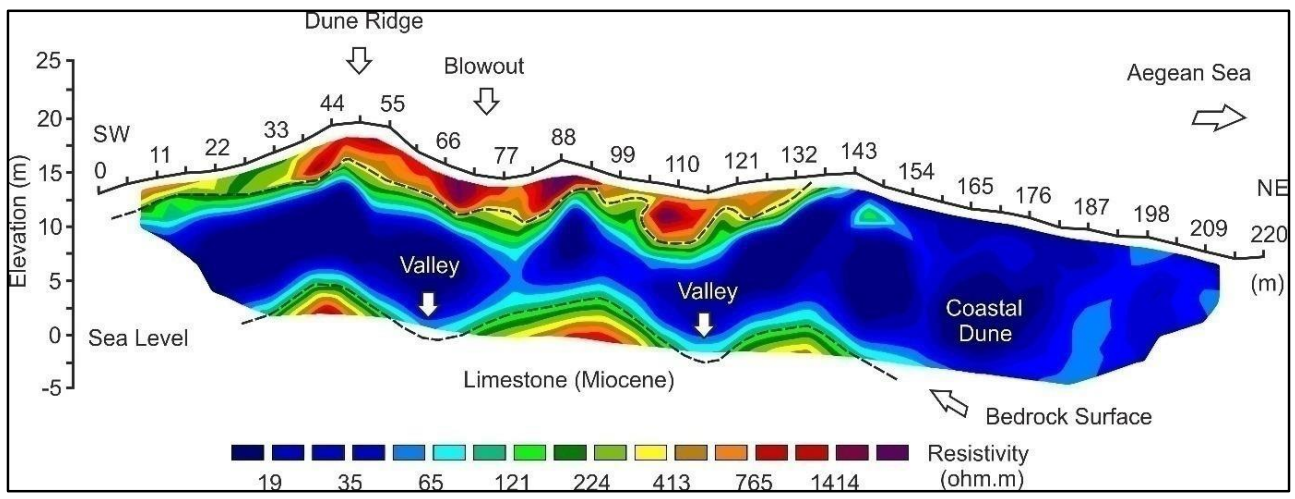

Figure 7. Electrical resistivity tomogram of surveyed line obtained from the inversion of apparent resistivity data.

Table 1 Several measured parameters of incipient foredune materials. P1 and P2 refer to samples taken from dune ramp slope and ridge, respectively.

\begin{tabular}{|c|c|c|c|c|c|c|c|c|c|c|}
\hline & \multicolumn{4}{|c|}{ Measured parameters } & \multicolumn{6}{|c|}{ Grain size (mm) } \\
\hline Profile & $\mathrm{EC}$ & $\mathrm{pH}$ & $\% \mathrm{CaCO}_{3}$ & \%O.M. & $2-1$ & $1-0.5$ & $0.5-$ & & $0.25-0.163$ & $\leq 0.163$ \\
\hline p1-1 & 260 & 7.74 & 1.10 & 0.28 & 0.15 & 3.99 & 49. & & 43.65 & 3.08 \\
\hline p1-2 & 635 & 8.25 & 1.88 & 0.32 & 0.45 & 11.66 & 61 & & 25.12 & 1.09 \\
\hline $\mathrm{p} 1-3$ & 567 & 8.16 & 1.80 & 0.20 & 2.09 & 38.1 & 42 . & & 16.31 & 0.77 \\
\hline p1-4 & 616 & 7.95 & 1.88 & 0.28 & 0.34 & 8.4 & 56. & & 33.45 & 1.43 \\
\hline p2-1 & 165.2 & 7.92 & 1.33 & 0.11 & 3.55 & 12.73 & 47. & & 33.96 & 2.63 \\
\hline $\mathrm{p} 2-2$ & 144.3 & 7.98 & 1.25 & 0.14 & 1.27 & 11.73 & 50. & & 33.98 & 2.45 \\
\hline $\mathrm{p} 2-3$ & 154.4 & 8.02 & 1.65 & 0.35 & 1.25 & 28.86 & 51. & & 17.68 & 0.78 \\
\hline \multirow[t]{2}{*}{$\mathrm{p} 2-4$} & 207 & 8.13 & 1.41 & 0.07 & 0.89 & 9.87 & 52. & & 34.05 & 2.61 \\
\hline & & & & \multicolumn{3}{|c|}{ XRF results } & & & & \\
\hline Profile & \multicolumn{2}{|l|}{$\mathrm{SiO}_{2}$} & $\mathrm{Al}_{2} \mathrm{O}_{3}$ & $\mathrm{TiO}_{2}$ & \multicolumn{2}{|c|}{$\mathrm{Fe}_{2} \mathrm{O}_{3}$} & $\mathrm{CaO}$ & $\mathrm{MgO}$ & $\mathrm{Na}_{2} \mathrm{O}$ & $\mathrm{K}_{2} \mathrm{O}$ \\
\hline P1-1 & \multicolumn{2}{|l|}{85.41} & 7.96 & 0.03 & \multicolumn{2}{|c|}{0.48} & 1.26 & 0.01 & 1.49 & 1.85 \\
\hline $\mathrm{P} 1-2$ & \multicolumn{2}{|l|}{84.79} & 8.02 & 0.09 & \multicolumn{2}{|c|}{0.41} & 1.57 & 0.01 & 1.32 & 1.92 \\
\hline P1-3 & \multicolumn{2}{|l|}{84.94} & 6.97 & 0.06 & \multicolumn{2}{|c|}{0.45} & 2.41 & 0.11 & 0.80 & 1.80 \\
\hline P1-4 & \multicolumn{2}{|l|}{85.09} & 8.22 & 0.09 & \multicolumn{2}{|c|}{0.38} & 1.36 & 0.01 & 1.34 & 1.99 \\
\hline P2-1 & \multicolumn{2}{|c|}{85.22} & 7.60 & 0.11 & \multicolumn{2}{|c|}{0.44} & 1.73 & 0.01 & 1.27 & 1.91 \\
\hline P2-2 & \multicolumn{2}{|l|}{85.12} & 7.83 & 0.12 & \multicolumn{2}{|c|}{0.45} & 1.48 & 0.01 & 1.48 & 2.00 \\
\hline P2-3 & \multicolumn{2}{|l|}{85.68} & 7.61 & 0.08 & \multicolumn{2}{|c|}{0.38} & 1.52 & 0.01 & 1.08 & 1.93 \\
\hline P2-4 & \multicolumn{2}{|l|}{84.68} & 8.20 & 0.16 & \multicolumn{2}{|c|}{0.48} & 1.50 & 0.01 & 1.51 & 1.89 \\
\hline
\end{tabular}

EDX results

\begin{tabular}{ccccccccc}
\hline Profile & $\mathrm{C}$ & $\mathrm{O}$ & $\mathrm{Mg}$ & $\mathrm{Al}$ & $\mathrm{Si}$ & $\mathrm{K}$ & $\mathrm{Ca}$ & $\mathrm{Fe}$ \\
\hline P1-1 & 5.51 & 50.01 & 1.65 & 6.6 & 33.04 & 0.8 & 1.44 & 0.96 \\
P1-1 & 3.22 & 40.52 & 0.46 & 3.18 & 46.68 & 1.11 & 0.79 & 4.05 \\
P1-1 & 8.3 & 41.98 & 0.89 & 2.5 & 41.04 & 0.81 & 0.79 & 3.7 \\
P1-4 & 3.37 & 42.95 & 0.9 & 8.57 & 36.49 & 6.96 & 0.75 & 0 \\
P1-4 & 4.2 & 41.87 & 0.81 & 1.89 & 49.27 & 0.98 & 0.98 & 0 \\
P1-4 & 2.62 & 43.2 & 0.89 & 2.19 & 50.5 & 0.6 & 0 & 0 \\
\hline
\end{tabular}


Table 2. The lists of vegetation present in different zones in the Bozcaada dune field.

\begin{tabular}{|c|c|c|}
\hline Taxon name & Life form & Location \\
\hline $\begin{array}{l}\text { Aetheorhiza bulbosa subsp. } \\
\text { microcephala }\end{array}$ & Tuberous perennial & $\begin{array}{l}\text { Foredune terraces, foredune ridges, } \\
\text { interdune depressions }\end{array}$ \\
\hline $\begin{array}{l}\text { Ammophila arenaria subsp. } \\
\text { arundinacea }\end{array}$ & $\begin{array}{l}\text { Rhizomatous } \\
\text { perennial }\end{array}$ & Foredune terraces, foredune ridges \\
\hline $\begin{array}{l}\text { Anthemis tomentosa subsp. } \\
\text { tomentosa }\end{array}$ & Annual & Foredune terraces, foredune ridges \\
\hline $\begin{array}{l}\text { Centaurea spinosa var. } \\
\text { spinosa }\end{array}$ & $\begin{array}{l}\text { Perennial, cushion } \\
\text { form }\end{array}$ & Foredune terraces, foredune ridges \\
\hline $\begin{array}{l}\text { Cynodon dactylon var. } \\
\text { dactylon }\end{array}$ & $\begin{array}{l}\text { Rhizomatous } \\
\text { perennial }\end{array}$ & $\begin{array}{l}\text { Foredune terraces, interdune } \\
\text { depressions }\end{array}$ \\
\hline Eryngium maritimum & Perennial herb & Foredune terraces, foredune ridges \\
\hline Euphorbia paralias & Perennial herb & Foredune terraces, foredune ridges \\
\hline Imperata cylindrica & Perennial herb & Foredune terraces \\
\hline Medicago marina & Annual & Foredune terraces, foredune ridges \\
\hline Otanthus maritimus & Perennial herb & $\begin{array}{l}\text { Foredune terraces, foredune ridges, } \\
\text { interdune depressions }\end{array}$ \\
\hline Parapholis incurva & Annual & Foredune terraces \\
\hline $\begin{array}{l}\text { Elymus farctus subsp. farctus } \\
\text { var. Farctus }\end{array}$ & $\begin{array}{l}\text { Rhizomatous } \\
\text { perennial }\end{array}$ & Foredune terraces \\
\hline Cyperus capitatus & $\begin{array}{l}\text { Rhizomatous } \\
\text { perennial }\end{array}$ & Foredune ridges \\
\hline $\begin{array}{l}\text { Elymus elongatus subsp. } \\
\text { elongatus }\end{array}$ & $\begin{array}{l}\text { Rhizomatous } \\
\text { perennial }\end{array}$ & Foredune ridges \\
\hline Glaucium flavum & Biennial & $\begin{array}{l}\text { Foredune ridges, interdune } \\
\text { depressions }\end{array}$ \\
\hline Pancratium maritimum & Bulbous perennial & Foredune ridges \\
\hline Anthyllis hermanniae & Perennial shrub & Interdune depressions \\
\hline Avena barbata & Annual & Interdune depressions \\
\hline Blackstonia perfoliata & Annual & Interdune depressions \\
\hline Bromus tectorum & Annual & Interdune depressions \\
\hline Carlina corymbosa & Perennial herb & Interdune depressions \\
\hline Cistus creticus & Perennial shrub & Interdune depressions \\
\hline Coridothymus capitatus & Perennial shrub & Interdune depressions \\
\hline $\begin{array}{l}\text { Dactylis glomerata subsp. } \\
\text { hispanica }\end{array}$ & Perennial herb & Interdune depressions \\
\hline Dorychnium hirsutum & Perennial shrub & Interdune depressions \\
\hline Echium angustifolium & Perennial herb & Interdune depressions \\
\hline $\begin{array}{l}\text { Erodium cicutarium subsp. } \\
\text { cicutarium }\end{array}$ & Annual & Interdune depressions \\
\hline $\begin{array}{l}\text { Eryngium campestre var. } \\
\text { campestre }\end{array}$ & Perennial herb & Interdune depressions \\
\hline $\begin{array}{l}\text { Fumana thymifolia var. } \\
\text { thymifolia }\end{array}$ & Perennial shrub & Interdune depressions \\
\hline $\begin{array}{l}\text { Helichrysum stoechas subsp. } \\
\text { barrelieri }\end{array}$ & Perennial & Interdune depressions \\
\hline Hypochoeris glabra & Annual & Interdune depressions \\
\hline Juncus acutus & Perennial & Interdune depressions \\
\hline Lagurus ovatus & Annual & Interdune depressions \\
\hline
\end{tabular}




\begin{tabular}{lll}
\hline Limonium virgatum & Perennial herb & Interdune depressions \\
Malcolmia flexuosa & Annaul & Interdune depressions \\
Medicago constricta & Annual & Interdune depressions \\
Onobrychis caput-galli & Annual & Interdune depressions \\
Orobanche ramosa & Annual parasites & Interdune depressions \\
Phragmites australis & Rhizomatous & Interdune depressions \\
& perennial & \\
Pinus brutia & Tree & Interdune depressions \\
Pistacia lentiscus & Perennial & Interdune depressions \\
Rubia tenuifolia subsp. & Perennial sub- & Interdune depressions \\
tenuifolia & shrub & \\
Sarcopoterium spinosum & Perennial, cushion & Interdune depressions \\
& form & \\
Scipoides holoschoenus & Perennial herb & Interdune depressions \\
Shoenus nigricans & Perennial herb & Interdune depressions \\
Teucrium polium & Perennial herb & Interdune depressions \\
Thymelaea tartonraira & Perennial shrub & Interdune depressions \\
Tragopogon porrifolius & Annual & Interdune depressions \\
Vulpia membranacea & Annual & Interdune depressions \\
Osyris alba & Perennial, & Interdune depressions \\
& semiparasites & \\
\hline
\end{tabular}

Table 3. Several measured parameters of swale materials.

\begin{tabular}{|c|c|c|c|c|c|c|c|c|c|}
\hline & \multicolumn{4}{|c|}{ Measured parameters } & \multicolumn{5}{|c|}{ Grain size (mm) } \\
\hline Profile & $\mathrm{EC}$ & $\mathrm{pH}$ & $\% \mathrm{CaCO}_{3}$ & $\%$ O.M. & $2-1$ & $1-0.5$ & $0.5-0.25$ & $0.25-0.163$ & $\leq 0.163$ \\
\hline P3-1 & 182.3 & 8.18 & 3.45 & 0.84 & 7.48 & 12.91 & 26.89 & 38.32 & 14.31 \\
\hline P3-2 & 213 & 8.07 & 3.29 & 0.57 & 5.94 & 13.46 & 27.35 & 38.69 & 14.53 \\
\hline P3-3 & 190.4 & 7.92 & 3.14 & 0.47 & 6.61 & 15.5 & 26.76 & 38.19 & 12.83 \\
\hline P3-4 & 247 & 8.07 & 12.54 & 1.33 & 22.16 & 28.35 & 21.77 & 17.38 & 10.32 \\
\hline \multicolumn{10}{|c|}{ XRF results } \\
\hline Profile & $\mathrm{SiO}_{2}$ & & $\mathrm{Al}_{2} \mathrm{O}_{3}$ & $\mathrm{TiO}_{2}$ & $\mathrm{Fe}_{2} \mathrm{O}_{3}$ & $\mathrm{CaO}$ & $\mathrm{MgO}$ & $\mathrm{Na}_{2} \mathrm{O}$ & $\mathrm{K}_{2} \mathrm{O}$ \\
\hline P3-1 & 82.2 & & 7.87 & 0.15 & 0.69 & 2.84 & 0.01 & 1.25 & 1.92 \\
\hline P3-2 & 81.4 & & 7.93 & 0.15 & 0.75 & 3.34 & 0.01 & 1.13 & 1.90 \\
\hline P3-3 & 81.6 & & 7.78 & 0.13 & 0.66 & 3.41 & 0.01 & 1.15 & 1.85 \\
\hline P3-4 & 66.9 & & 8.11 & 0.24 & 1.73 & 10.01 & 0.54 & 0.73 & 1.74 \\
\hline \multicolumn{10}{|c|}{ EDX results } \\
\hline Profile & & $\bar{C}$ & $\mathrm{O}$ & $\mathrm{Mg}$ & $\mathrm{Al}$ & $\mathrm{Si}$ & $\mathrm{K}$ & $\mathrm{Ca}$ & $\mathrm{Fe}$ \\
\hline P3-1 & & 38 & 40.20 & 2.22 & 9.35 & 24.98 & 3.67 & 4.78 & 5.51 \\
\hline P3-1 & & 58 & 46.53 & 2.22 & 10.48 & 25.24 & 2.39 & 1.11 & 2.47 \\
\hline P3-1 & & 16 & 25.95 & 1.34 & 5.83 & 15.26 & 2.21 & 2.14 & 33.11 \\
\hline P3-4 & & 94 & 41.69 & 1.82 & 8.01 & 22.74 & 3.41 & 12.40 & 0 \\
\hline P3-4 & & 76 & 43.85 & 1.65 & 6.36 & 34.34 & 0.65 & 5.40 & 0 \\
\hline P3-4 & & 71 & 42.78 & 2.39 & 9.60 & 19.10 & 2.94 & 1.49 & 0 \\
\hline
\end{tabular}


Table 4 Long-term monthly and annual mean wind speeds $\left(\mathrm{m} \mathrm{s}^{-1}\right)$ arranged in accordance with 16 (8 main and 8 interval) directions and long-term averages of monthly and annual mean wind speeds ( $\mathrm{m}$ $\mathrm{s}^{-1}$ ) of Bozcaada station regardless of direction. (*) Bold indicates the maximum mean and highest wind speeds that month.

\begin{tabular}{lccccccccccccc}
\hline & \multicolumn{1}{c}{} & \multicolumn{1}{c}{ Month } & & & & \\
\hline Direction & J & F & M & A & M & J & J & A & S & O & N & D & Annual \\
\hline N & $\mathbf{9 . 2}(*)$ & 7.6 & $\mathbf{8 . 6}$ & 6.0 & $\mathbf{6 . 0}$ & $\mathbf{5 . 7}$ & $\mathbf{7 . 1}$ & $\mathbf{6 . 8}$ & $\mathbf{7 . 1}$ & $\mathbf{7 . 7}$ & 6.8 & $\mathbf{9 . 2}$ & $\mathbf{7 . 1}$ \\
NNE & $\mathbf{8 . 7}$ & $\mathbf{9 . 1}$ & $\mathbf{8 . 2}$ & $\mathbf{6 . 6}$ & $\mathbf{6 . 0}$ & $\mathbf{5 . 5}$ & $\mathbf{6 . 5}$ & $\mathbf{7 . 1}$ & $\mathbf{7 . 1}$ & $\mathbf{8 . 4}$ & $\mathbf{8 . 2}$ & $\mathbf{8 . 5}$ & $\mathbf{7 . 4}$ \\
NE & 8.2 & $\mathbf{9 . 0}$ & 7.7 & 5.7 & 5.5 & 5.2 & 4.9 & 6.1 & 5.7 & $\mathbf{6 . 8}$ & $\mathbf{7 . 9}$ & $\mathbf{8 . 8}$ & 7.1 \\
ENE & 5.7 & 6.2 & 5.8 & 3.9 & 3.3 & 3.0 & 4.0 & 4.8 & 3.7 & 4.3 & 5.3 & 5.8 & 4.9 \\
E & 3.8 & 4.6 & 4.2 & 2.5 & 2.6 & 2.2 & 2.7 & 2.7 & 2.7 & 3.2 & 3.6 & 4.0 & 3.4 \\
ESE & 3.8 & 4.1 & 3.1 & 3.0 & 2.1 & 1.8 & 1.8 & 2.0 & 2.0 & 2.3 & 3.1 & 3.7 & 3.0 \\
SE & 5.3 & 5.0 & 4.1 & 3.2 & 2.4 & 2.4 & 1.4 & 1.8 & 2.1 & 2.7 & 3.8 & 4.8 & 3.6 \\
SSE & 7.8 & $\mathbf{8 . 4}$ & 7.3 & $\mathbf{6 . 4}$ & 5.2 & 3.7 & 3.0 & 2.6 & 4.5 & 5.7 & 6.7 & 8.1 & 6.7 \\
S & 7.7 & 8.2 & $\mathbf{7 . 8}$ & $\mathbf{6 . 5}$ & $\mathbf{5 . 7}$ & 4.7 & 2.6 & 3.8 & 5.0 & 6.1 & $\mathbf{7 . 4}$ & 7.9 & $\mathbf{7 . 0}$ \\
SSW & $\mathbf{8 . 5}$ & 7.7 & 7.1 & 6.2 & 5.0 & 4.7 & 3.6 & 4.4 & 4.6 & 5.5 & 6.7 & 8.2 & 6.4 \\
SW & 7.1 & 6.3 & 6.5 & 5.4 & 4.4 & 4.8 & 3.7 & 3.5 & 4.6 & 4.6 & 6.0 & 6.4 & 5.3 \\
WSW & 4.9 & 4.4 & 4.3 & 4.3 & 3.8 & 3.8 & 3.7 & 3.7 & 3.7 & 3.7 & 3.5 & 4.1 & 4.0 \\
W & 5.1 & 4.5 & 4.8 & 2.9 & 3.2 & 3.9 & 3.4 & 4.5 & 4.3 & 3.3 & 3.0 & 4.1 & 3.9 \\
WNW & 4.0 & 4.3 & 4.5 & 4.0 & 4.2 & 4.3 & 4.5 & 4.4 & 4.4 & 5.4 & 4.1 & 4.4 & 4.4 \\
NW & 2.8 & 3.6 & 4.4 & 4.3 & 4.9 & 5.4 & 5.6 & 6.0 & 5.6 & 4.8 & 3.7 & 4.6 & 5.0 \\
NNW & 5.9 & 5.6 & 6.4 & 5.5 & 5.3 & $\mathbf{5 . 8}$ & $\mathbf{6 . 6}$ & $\mathbf{7 . 0}$ & $\mathbf{6 . 7}$ & 6.1 & 5.2 & 5.7 & 6.2 \\
\hline Average & 6.2 & 6.2 & 5.9 & 4.8 & 4.4 & 4.2 & 4.1 & 4.5 & 4.6 & 5.0 & 5.3 & 6.1 & 5.3 \\
\hline
\end{tabular}

Table 5 Thornthwaite water budget of Bozcaada meteorology station for period 1975-2005.

\begin{tabular}{llllllllllllll}
\hline Variables & Jan & Feb & Mar & Apr & May & June & July & Aug & Sep & Oct & Nov & Dec & Total \\
\hline TEMP $^{1}$ & 8.4 & 8.3 & 9.8 & 13.6 & 17.3 & 21.5 & 23.1 & 23.0 & 20.7 & 16.9 & 12.7 & 9.8 & \\
UPE$^{2}$ & 22 & 21 & 28 & 47 & 68 & 96 & 108 & 107 & 91 & 66 & 42 & 28 & \\
APE$^{3}$ & 18 & 18 & 28 & 51 & 84 & 119 & 136 & 126 & 93 & 63 & 35 & 23 & 794 \\
PREP $^{4}$ & 70 & 57 & 52 & 40 & 25 & 11 & 6 & 5 & 17 & 25 & 70 & 86 & 465 \\
DIFF $^{5}$ & 52 & 40 & 23 & -11 & -59 & -108 & 130 & -120 & -76 & -38 & 35 & 63 & \\
ST $^{6}$ & 100 & 100 & 100 & 90 & 49 & 16 & 4 & 1 & 1 & 0 & 36 & 99 \\
CST $^{7}$ & 1 & 0 & 0 & -10 & -40 & -33 & -12 & -3 & -1 & 0 & 35 & 63 & \\
AE $^{8}$ & 18 & 18 & 28 & 51 & 65 & 44 & 18 & 8 & 18 & 25 & 35 & 23 & 351 \\
DEF $^{9}$ & 0 & 0 & 0 & 1 & 19 & 75 & 118 & 117 & 75 & 37 & 0 & 0 & 443 \\
SURP $^{10}$ & 51 & 40 & 23 & 0 & 0 & 0 & 0 & 0 & 0 & 0 & 0 & 0 & 114 \\
\hline
\end{tabular}

(1) Air temperature (TEMP) in ${ }^{\circ} \mathrm{C}$, (2) Unadjusted potential evapotranspiration (UPE) in $\mathrm{mm}$, (3) Adjusted potential evapotranspiration (APE) in $\mathrm{mm}$, (4) Precipitation (PREC) in $\mathrm{mm}$, (5) Precipitation minus APE (DIFF) in $\mathrm{mm}$, (6) Soil moisture storage (ST) in $\mathrm{mm}$, (7) Change in storage from the preceding month (CST) in mm, (8) Actual evapotranspiration (AE) in $\mathrm{mm}$, (9) Soil moisture deficit (DEF) in mm, (10) Soil moisture surplus (SURP) in mm

\section{Acknowledgement}

We thank Dr. Aydın Büyüksaraç for his permission to use resistivity meter in the research. The modeling procedures of the resistivity data were carried out at the Earthquake Monitoring and Data Processing Laboratory (DEIVIL) in
Department of Geophysical Engineering at Çanakkale. Graham Lee is thanked for putting effort into linguistic corrections of the paper. This study was supported financially by the project no 2008/32 and partially supported by the project no 2010/162 of the Research Foundation of Çanakkale Onsekiz Mart University. 


\section{References}

Bate, G., Ferguson, M. (1996). Blowouts in coastal foredunes. Landscape and Urban Planning, 34 (3-4), 215-224.

Bouyoucos, G.J. (1951). A recalibration of the hydrometer method for making mechanical analysis of soils. Agronomy Journal 43, 434-438.

Cooper, W.S. (1958). Coastal sand dunes of Oregon and Washington. Geological Society of America Memoir 72. Waverly Press, Inc. Baltimore, MD.

Davis, P.H. (1965-1985). Flora of Turkey and the East Aegean Islands, Volumes 1-9. Edinburgh: Edinburgh University Press.

Erginal, A.E., Ekinci, Y.L., Demirci, A., Avcıŏglu, M., Öztürk, M.Z., Türkeş, M., Yiğitbaş, E. (2013). Depositional characteristics of carbonate-cemented fossil eolian sand dunes: Bozcaada Island, Turkey. Journal of Coastal Research 29 (1), 78-85.

Erginal, A.E., Kıyak, N.G., Özcan, H. (2009). Optically Stimulated Luminescence to date coastal dunes and a possible Tsunami layer on the Kavak delta (Saros Gulf, NW Turkey). Turkish Journal of Earth Sciences 18 (3), 465-474.

Erguvanl1, K. (1955). Geological study of the Bozcaada Island. Bulletin de la Société Géologique de France 6, 399-401 (in French).

Fraser, G.S., Bennett, S.W., Olyphant, G.A., Bauch, N.J., Ferguson, V., Gellasch, C.A., Millard, C.L., Mueller, B., O'malley, P.J., Way, N., Woodfield, M.C. (1998). Windflow circulation patterns in a coastal dune blowout, south coast of Lake Michigan. Journal of Coastal Research 14 (2), 451460.

Grewelling, T., Peech, M. (1960). Chemical Soil Test. Cornell University Agricultural Experiment Station Bulletin, New York.

Hamidi, N., Kayaalp, N. (2008). Estimation of the amount of suspended sediment in the Tigris River using artificial neural networks. Clean- Air Soil Water, 36 (4), 380386.

Hesp, P. (2002). Foredunes and blowouts: initiation, geomorphology and dynamics. Geomorphology, 48 (1-3), 245-268.
Hugenholtz, C.H., Wolfe, S.A. (2009). Formflow interactions of an eolian saucer blowout. Earth Surface Processes and Landforms, 34 (7), 919-928.

Kalafatçıoglu, A. (1963). Geology of the environs of Ezine and Bozcaada; age of limestones and serpanites. Bulletin of the Mineral Research and Exploration 60, 60-69 (in Turkish).

Karabacak, E., Erginal, A.E., Özmen, H. (2008). Flora and mapping of dune vegetation of the Bozcaada-Batıburnu area. Symposium of Bozcaada Values, Abstracts Book, Aynalı Pazar Yayınevi, Bozcaada, 183-191 (in Turkish).

Kıyak, N.G., Erginal, A.E. (2009). Optical Stimulated Luminescence dating study of eolianite on the Island of Bozcaada, Turkey: preliminary results. Journal of Coastal Research, 26 (4), 673-680.

Loke, M.H., Barker, R.D. ( 1996). Rapid leastsquares inversion of apparent resistivity pseudosections using a quasi-Newton method. Geophysical Prospecting 44 (1), 131-152.

Özcan, H., Akbulak, C., Kelkit, A., Tosunoğlu, M., Uysal, I. (2009a). Ecotourism potential and management of Kavak Delta. Journal of Coastal Research 25 (3), 781787.

Özcan, H., Erginal, A.E., Akbulak, C., Sungur, A., Bozcu, M. (2009b). Physico-chemical characteristics of coastal dunes on the Saros Gulf, Turkey. Journal of Coastal Research 26 (1), 132-142.

Özhan, E. (2005). Coastal area management in Turkey.Priority Actions Programme Regional Activity Centre (PAP/RAC). Coastal Area Management in Turkey, Split..

Öztürk, F. (1996). Suspended sediment yields of rivers in Turkey. In: Erosion and Sediment Yield: Global and Regional Perspectives. Proceedings of the Exeter Symposium: 6571.

Şahin, A.D. (2008). A Review of Research and Development of Wind Energy in Turkey. Clean-Soil Air Water 36 (9), 734-742.

Schlicting E, Blume E. (1966). Bodenkundliches practicum. Hamburg und Berlin: Verlag Paul Parey. 
Soil Survey Staff, (1993). Soil Conservation Service National Soil Survey Handbook Part 618, Title 430-VI, US Dept of Ag. (USDA), US Govt Printing Office, Washington DC.

Serteser, A. (2004). Assessment of coastal dunes in Ceyhan Delta (Adana) with regards to vegetation and soil relatioships. V. National Conference on Turkey's Coastal and Marine Areas, Abstracts Book, 1, 17-24 (in Turkish).

Sesli, F.A., Karslı, F., Çölkesen, I., Akyol, N. (2009). Monitoring the changing position of coastlines using aerial and satellite image data: an example from the eastern coast of Trabzon, Turkey. Environmental Monitoring and Assessment 153, 391-403.

Smith, H.T.U. (1960). Physiography and photo interpretation of coastal sand dunes. Final Report Contract NONR - 2242(00), Office of Naval Research, Geographical Branch.

Thornthwaite, C.W. (1948). An Approach toward a rational classification of climate. Geography Review, 38, 55-94.

Tutin, T.G., Heywood, V.H., Burges, N.A., Moore, D.M., Valentine, D.H. (19641980). Flora Europaea Volume 1-5. Cambridge: Cambridge University Press.

Türkeş, M. (1996). Spatial and temporal analysis of annual rainfall variations in Turkey. International Journal of Climatology, 16 (9),1057-1076.

Türkeş, M. (1998). Influence of geopotential heights, cyclone frequency and Southern Oscillation on rainfall variations in Turkey. International Journal of Climatology, 18 (6), 649-680.

Türkeş, M., Erlat, E. (2005). Climatological responses of winter precipitation in Turkey to variability of the North Atlantic Oscillation during the period 1930-2001. Theoretical and Applied Climatology 81 (1-2), 45-69.

Türkeş, M., Koç, T., Sarış, F. (2009). Spatiotemporal variability of precipitation total series over Turkey. International Journal of Climatology 29 (8), 1056-1074.

Uslu, T. (1989). Geographical Information on Turkish Coastal Dunes. European Union for Dune Conservation and Coastal Management Publications, Leiden.
Wang, S., Hasi, E., Zhang, J., Zhang, P. (2007). Geomorphological significance of air flow over saucer blowout of the Hulun Buir sandy grassland. Journal of Desert Research 2007 (5), 745-749.

Willmott, C.J. (1977). Watbug: A Fortran IV Algorithm for Calculating the Climatic Water Budget. Newark, Delaware: Water Resources Center, University of Delaware.

$\mathrm{Yu}$, Jian Zhen, Xiao-Feng Huang, Jinhui Xu, and Min $\mathrm{Hu}$. (2005)"When aerosol sulfate goes up, so does oxalate: Implication for the formation mechanisms of oxalate." Environmental science \& technology 39 (1), 128-133.

Zuo, Yuegang, and Juerg Hoigne. (1992) "Formation of hydrogen peroxide and depletion of oxalic acid in atmospheric water by photolysis of iron (III)-oxalato complexes." Environmental Science \& Technology 26, no. 5: 1014-1022. 